\title{
Um antropólogo no museu: Edgar Roquette-Pinto e o exercício da antropologia no Brasil nas primeiras décadas do século $\mathrm{XX}$
}

\section{An anthropologue at the museum:}

Edgar Roquette-Pinto and the exercise of anthropology in the first decades of the 20th century

\author{
Rita de Cássia Melo Santos ${ }^{*}$ \\ *Universidade Federal da Paraíba - João Pessoa, PB, Brasil \\ santos.cm.rita@gmail.com \\ https://orcid.org/0000-0001-9368-6176
}




\title{
Resumo
}

O presente artigo pretende explorar as conexões entre antropologia e museus a partir da trajetória de Edgar Roquette-Pinto. Antropólogo formado em medicina, Roquette-Pinto teve uma atuação determinante nos museus Nacional e Paulista. Nesses espaços formou coleções, elaborou catálogos e materiais de divulgação, promoveu exposições. Espera-se, por meio da análise de sua trajetória e atuação, discutir os processos de formação profissional do antropólogo na primeira metade do século XX; as fronteiras existentes na classificação dos museus como nacionais e etnográficos; bem como apontar para a função pública e política dos museus a partir da sua relação com a antropologia.

Palavras-chave: Roquette-Pinto; antropologia; museus; exposições etnográficas.

\begin{abstract}
The present article intends to explore the connections between anthropology and museums from the trajectory of Edgar Roquette-Pinto. Anthropologue trained in medicine, Roquette-Pinto played a decisive role in the National and Paulista museums. In these spaces formed collections, elaborated catalogs and materials of publicity, promoted exhibitions. Expected, through the analysis of its trajectory and performance, the boundaries in the classification of museums as national and ethnographic; as well as to point to the public and political function of museums from their relationship with anthropology.
\end{abstract}

Keywords: Roquette-Pinto; anthropology; museums; ethnographic exhibitions. 


\section{Introdução}

A minha entrada na antropologia a partir de 2006 foi realizada por meio de um caminho pouco usual para os jovens pesquisadores da época. Advinda de uma graduação em história, havia sido selecionada como bolsista de iniciação científica num projeto de produção de uma exposição antropológica sobre os índios do Nordeste. Fui incumbida, na ocasião, de realizar levantamentos os mais diversos: desde coleções de museus até relatos de viajantes sobre as populações que haveríamos de apresentar. Passava os dias vasculhando os catálogos das instituições museais da região, visitando seus acervos e lendo livros de viagens. Depois, já nas múltiplas montagens, pensava em conjunto com a curadoria, os percursos narrativos, a mediação com o público, a formação dos mediadores. ${ }^{1}$

Embora o trabalho realizado tivesse muita relação com a origem histórica da disciplina e com a "virada material" que foi processada em fins do século XX (Appadurai, 2008; Tilley et al., 2006), no começo do século XXI, a atuação dos antropólogos ainda era reconhecida por meio do "trabalho de campo". Adentrar os museus, suas reservas técnicas, vasculhar arquivos não constituía de fato o elemento sedutor que a "ida a campo" despertava nos neófitos da disciplina. Se a imersão no mundo dos museus, num primeiro momento, me afastou dos meus pares estudantes que buscavam os cantos mais distantes do país e do exterior para realizarem suas pesquisas, por outro lado, me aproximou de um conjunto muito amplo de antropólogos mais velhos e pretéritos que ali desenvolveram seus trabalhos. Desenvolvi uma curiosidade especial pelo trabalho de Edgar Roquette-Pinto cuja trajetória e modos de colecionar foram alvo da minha dissertação de mestrado, defendida no PPGAS/Museu Nacional/UFRJ (Santos, 2011) e cuja pesquisa aqui recupero como caminho para discutir três aspectos pertinentes às relações entre antropologia e museus hoje.

O primeiro diz respeito ao museu como espaço de formação de antropólogos. Se a partir da década de 1970 os programas de pós-graduação passaram,

1 O processo de formulação da exposição e suas principais contribuições foram objeto de análise no artigo de Oliveira e Santos (2016). 
no Brasil, a responder de modo mais ativo por essa formação (Garcia, 2009; Oliveira, 2010); foi nos museus do início do século que os jovens pesquisadores quase sempre realizavam a virada formativa da medicina para a antropologia. A aproximação com a área de anatomia nos cursos médicos respondia por essa entrada inicial na disciplina (Castro Faria, 2006) que, passada a fase de descoberta, era consolidada no interior dos museus. Era em suas galerias, exposições e trabalhos complementares que os então médicos passavam a ser reconhecidos e se reconheciam como antropólogos. Esse foi o caso das trajetórias de Batista de Lacerda e Edgar Roquette-Pinto - para citar apenas dois dos principais antropólogos desse período. O processo de constituição da antropologia na virada do século XIX para o XX e de produção desses antropólogos serão analisados nas duas primeiras partes do artigo, "O Museu Nacional e a constituição da antropologia no Brasil" e "O museu como espaço de formação prática em antropologia".

O segundo aspecto que este artigo pretende abordar é espaço da etnografia no interior do que veio a se constituir como museus nacionais. Se hoje a oposição entre museu etnográfico e museu nacional parece consolidada e, muitas vezes, é apontada como uma disputa entre os "lugares de memória", respectivamente, das "nações" e dos "povos subalternizados", durante todo o século XIX e começo do século XX, a etnografia correspondeu a um processo complementar à constituição da história nacional. Ela respondia pela construção histórica sobre "os povos sem história" (Wolf, 1982) e foi um mecanismo fundamental na construção da narrativa sobre as populações autóctones do Brasil (Kodama, 2009; Oliveira, 2016; Veloso Júnior, 2013).

Nesse sentido, na terceira parte do artigo, "A refundação antropológica das exposições do Museu Nacional e do Museu Paulista", pretendo demonstrar como a antropologia praticada no período utilizou as exposições etnográficas situadas no interior dos museus nacionais e históricos para comunicar suas interpretações sobre as populações autóctones ao grande público.

Minha hipótese é que as exposições constituíam em si mesmas um espaço de produção de conhecimento sobre essas populações a partir da geografia, da linguística e dos objetos tomados como material fundamental de análise. As exposições aqui descritas confirmam a influência da geografia sobre a antropologia para o período analisado, como já apontado por Castro Faria (1993), e permitem nos aprofundarmos nos modos como essa influência se materializou 
na produção do conhecimento antropológico. Esse é um ponto fundamental no sentido em que a relação entre etnografia e história nacional aparece consolidada para o século XIX, porém eclipsada pela refundação do "trabalho de campo" e da etnografia na disciplina a partir das primeiras décadas do século XX. Analisar, portanto, as exposições etnográficas no interior dos museus nacionais e históricos demonstra não somente como aquela relação entre etnografia e história foi prolongada até meados do século XX, assim como foi atualizada a partir do diálogo com outras disciplinas.

Por fim, já nas considerações finais, recupero a função pública e política dos museus a partir da sua relação com a antropologia. Através da atuação de Edgar Roquette-Pinto, pretendo demonstrar as principais contribuições que a presença e a formação de antropólogos no interior dos museus possibilitou em termos de diálogo com o público, formação dos estudantes da educação básica e da produção de imagens mais diversificadas da população nacional, permitindo assim a constituição de horizontes comuns entre "nós" e "eles". A recuperação de todo esse processo formativo, expositivo e de diálogo com o público busca lançar perspectivas para a atuação dos antropólogos situados nos museus hoje ao mesmo tempo em que desafia os jovens pesquisadores a tomar parte desse processo profícuo e instigante que a disciplina (re)assumiu nas últimas décadas.

\section{O Museu Nacional e a constituição da antropologia no Brasil}

Quando, em 1905, Roquette-Pinto ingressou nos quadros técnicos do Museu Nacional através de um concurso público já havia sido trilhada uma longa trajetória de investimento científico no âmbito da antropologia naquela instituição. A existência de uma seção específica, denominada de "Antropologia, Etnologia e Arqueologia" resultava do esforço empreendido pelos diretores do Museu Nacional do Rio de Janeiro ao longo da segunda metade do século XIX. Notadamente, Ladislau Netto e Batista de Lacerda.

Ladislau Netto foi o diretor do Museu Nacional entre 1874 e 1893. Durante os quase 20 anos em que esteve à frente da instituição realizou importantes ações de consolidação da sua importância pública como centro produtor de conhecimento. Na sua época, inexistiam concursos de ingresso e ele iniciou os seus 
trabalhos no Museu Nacional como assistente de Freire Alemão. ${ }^{2}$ Durante o período de colaboração entre os dois, o Museu Nacional iniciou uma ativa participação na vida pública da metrópole. Ao buscar noticiar as pesquisas em curso em jornais e revistas, montar uma significativa biblioteca e promover conferências públicas que contavam com a presença do imperador e de outras figuras ilustres da corte, eles converteram o museu em órgão consultivo indispensável para sociedade brasileira de fins do século XIX (Castro Faria, 1998, p. 63).

É o próprio Ladislau Netto quem registra as mudanças decorrentes da visibilidade alcançada nesse período. Os objetos de história natural passaram a ser enviados mais frequentemente para o Museu Nacional, e outros puderam ser adquiridos. O governo passou a ter conhecimento da situação do museu e de suas necessidades mais urgentes (Netto, 1889, p. 8-9). Assim, em 1874, quatro anos após o falecimento de Freire Alemão, Ladislau, que era até então o seu substituto, foi nomeado diretor efetivo da instituição, cargo por ele ocupado até 1893. As mudanças, que haviam sido implementadas por Ladislau desde o período em que era assistente, a partir daí puderam ser intensificadas.

Com Ladislau Netto, a contratação de naturalistas viajantes tornou-se rotina, a ponto dessa categoria de trabalho ser incluída nos quadros técnicos do Museu Nacional. Ainda durante sua gestão, a instrução do público em geral foi implementada como uma das principais funções do museu. Embora estabelecida desde o regulamento de 1842, somente a partir de sua gestão isso se tornou de fato possível. Ladislau realizou ainda as ampliações físicas possíveis. ${ }^{3}$ Terminou a parte do edifício destinada à organização das coleções duplicadas, à secretaria, ao laboratório, ao isolamento das preparações zoológicas e botânicas. As reformas da fachada e dos salões situados no

2 Francisco Freire Alemão foi diretor do Museu Nacional entre os anos de 1866 e 1870. Sua ascensão ao cargo de diretor se deu por meio da sua proximidade com a família imperial, pois foi professor das princesas Leopoldina e Isabel, e do sucesso obtido com a realização da Comissão das Borboletas realizada entre os anos de 1859 e 1861. A comissão percorreu vários estados do Nordeste do Brasil, dentre eles Ceará, Piauí, Pernambuco, Paraíba e Rio Grande do Norte, e teve dentre os seus integrantes a presença de Gonçalvez Dias como responsável pela parte etnográfica e descritiva da viagem, enquanto Freire Alemão era responsável pela parte botânica e direção. Para uma contextualização das práticas etnográficas e das realizações de Freire Alemão, consultar o trabalho de Veloso Júnior (2013).

3 Nesse momento o Museu Nacional ocupava um edifício situado no Campo de Santana, na região central da cidade do Rio de Janeiro. 
primeiro piso foram realizadas no ano seguinte, bem como a abertura de novos salões (Netto, 1875, p. 15).

A ênfase num conhecimento de dimensão universal, que fora apontada por Lopes como uma das características do Museu Nacional em fins do século XIX, acompanhou a reformulação dos museus nacionais latino-americanos e europeus no mesmo período (Lopes, 1997, p. 126) e também do Museu Nacional. $O$ intercâmbio entre essas instituições, e a intensificação da dimensão universalista do museu, foi fortemente incentivado pelas reformas empreendidas por Ladislau, notadamente com a institucionalização da revista Arquivos e sua distribuição pela Europa e demais continentes. Lacerda (1905, p. 46), importante sucessor de Ladislau na direção do museu, ao se referir a esse período menciona que o Museu Nacional, a partir daí, passou a ser "considerado nos centros scientificos europeus a mais importante instituição deste genero na America do Sul".

Batista de Lacerda por sua vez participava ativamente da vida pública da instituição desde 1877. Utilizando a estrutura construída por Ladislau Netto, ministrou o primeiro curso de antropologia, dentro dos quadros de cursos públicos da época, considerado um marco na formação da disciplina no Brasil (Castro Faria, 1998, p. 20). O curso fora planejado em dois anos. "No primeiro, o estudo de anatomia e da fisiologia do homem. No seguinte, o estudo das raças humanas, especialmente o das raças americanas, abrangendo em parte as questões de herança, mestiçagem e aclimatação. Monogenismo e poligenismo ficarão para o fim" (cf. Castro Faria, 1999, p. 23).

As proposições de Lacerda correspondem ao processo mais amplo analisado por Stocking Jr. (1982) de incorporação dos debates de raça no discurso científico ao longo do século XIX e sua inserção no Brasil conforme o movimento apontado por Schwarcz (2004). Para a autora, mais do que transplantar diretamente o conceito de raça tal qual formulado pelos centros europeu para a América, os cientistas brasileiros promoveram a sua adaptação. Um exemplo dessas transmutações de sentido pode ser apontado com o elogio feito por Roquette-Pinto à mestiçagem, vista como degenerescência na Europa.

Como desdobramento do curso e desses debates, Batista de Lacerda propôs a realização de uma exposição antropológica prontamente aceita por Ladislau Netto. O diretor, apostando na dimensão etnográfica, nela percebeu a possibilidade de sobressair-se aos esforços dos americanistas e de elevar o Museu Nacional além do reconhecimento até então alcançado (Lacerda, 1905, p. 56). Para tanto, 
solicitou ao ministro que enviasse aos presidentes de Província ofícios requisitando a remessa de objetos que pudessem servir à exposição. A preparação para o evento iniciou-se ainda em 1881, com a solicitação de objetos, a recepção deles e a organização de expedições específicas para realização de novas coletas e escavações. Inicialmente houve resistência ao envio de objetos, mas, à medida que a exposição se aproximava, as remessas foram se intensificando.

Não era, obviamente, a primeira vez que Ladislau Netto realizava uma exposição. Além da exposição permanente do Museu Nacional, minuciosamente descrita em "Investigações" (Netto, 1870, p. 153-310), durante sua gestão ocorreu a "Exposição da Filadélfia”, em 1876, que permitiu a Ladislau experienciar uma exposição de grandes dimensões em âmbito internacional. Pôde também perceber a repercussão que as mostras levadas pela comissão brasileira despertavam no público. A coleção por ele preparada, por exemplo, foi tida como uma das mais notáveis. A composição que Hartt fez, com imagem dos botocudos, realizadas por Marc Ferrez, acompanhadas de réguas, foi replicada em exposições posteriores. Inclusive, na Exposição Antropológica de 1882 (Nascimento, 2009, p. 131). Demonstrando assim a importância que esses eventos tinham na projeção dos que lhes seguiam. ${ }^{4}$

Além das exposições promovidas pelo Museu Nacional, ou com sua participação, ocorreram nesse período outros grandes eventos expositivos, dentre os quais se destacam as exposições nacionais e estaduais, com regularidade desde 1861, para eleger os objetos que seriam remetidos às feiras mundiais; as exposições da Academia Imperial, desde 1879; e a "Exposição Nacional das Indústrias”, promovida pela Biblioteca Nacional em 1881 (Andermann, 2004, p. 129).

Se por um lado esses eventos promoveram, como afirma Andermann (2004), a descentralização do poder de representação do patrimônio cultural nacional pelo Museu Nacional, por outro eles ajudaram a construir uma familiaridade do público com a linguagem expositiva e um circuito colaborativo entre as instituições envolvidas. Além disso, segundo Castro Faria (1999, p. 24), a singularidade da exposição de 1882 residia tanto na ideia de sua concepção quanto nos resultados que a partir dela foram obtidos. Em relação aos resultados, tivemos, como principais, a consolidação da antropologia no Brasil enquanto

4 Para uma descrição detalhada das exposições realizadas no Museu Nacional desde a sua fundação, ver Castro Faria (1993) e Nascimento (2009, p. 95-142). 
disciplina autônoma e com métodos delimitados e a projeção internacional do Museu Nacional como instituição à qual esta disciplina estará referida. A realização dessa exposição em conjunto com o curso de antropologia constitui, portanto, a consolidação do campo antropológico no Brasil em fins do século XIX (Castro Faria, 1998, p. 20).

Em termos de ganhos materiais para o museu, com a Exposição Antropológica de 1882 as coleções dobraram de tamanho e o conhecimento produzido pôde ser propagado por um público bem mais amplo (Nascimento, 2009, p. 200), ao mesmo tempo em que as relações de envio de objetos com fins expositivos consolidaram-se entre governos provinciais, particulares e o Museu Nacional. Se o desejo por um museu etnográfico no Brasil, brevemente discutido no bojo dos debates sobre o regulamento de 1876, jamais se concretizou, Ladislau pôde, em parte, continuar a realizá-lo por meio das exposições. Por exemplo, em 1889, na Exposição Universal de Paris, realizada com o objetivo de comemorar o centenário da Revolução Francesa.

Os anos seguintes à República vieram conduzir Ladislau aos seus últimos atos à frente do Museu Nacional. A transferência de todas as coleções do museu para o edifício da Quinta da Boa Vista levou cerca de três anos, e marca os últimos momentos de Ladislau Netto, que seguiu acompanhando essa transposição até a sua aposentadoria, em 1893, quando entregou a direção geral a Domingos José Freire, importante pesquisador responsável pelos primeiros estudos dos modos de transmissão da febre amarela. ${ }^{5}$ Este a exerceu até 1895 , ano em que Batista de Lacerda retorna à instituição, agora em seu comando geral.

Quando assumiu a direção do Museu Nacional em 1895, Batista de Lacerda retomou o "espírito reformista" do museu. Todos os ajustes e ampliações necessários à exposição dos objetos, realizada durante o período no Campo de Santana, tiveram que ser refeitos em face das novas condições expositivas. Primeiramente, Lacerda retirou o pátio central que havia sido erguido para

5 Domingos José Freire foi diretor do Museu Nacional entre os anos de 1893 e 1895 . Uma década antes de iniciar a direção do museu, já havia sido reconhecido como um importante cientista, sobretudo na área de pesquisa relativa às causas da febre amarela. A sua vacina desenvolvida no início da década de 1880 já contava em 1883 com mais de duas mil pessoas vacinadas com êxito, o que levou à criação em 1892 do Instituto Bacteriológico Domingos Freire (Brasil, 1892). Para uma análise da atuação de Domingos José Freire na constituição do campo de bacteriologia no Brasil, ver o artigo de Benchimol (1995). 
o Congresso da Constituinte e o abriu para uma ampla galeria com planos sobrepostos. O mobiliário foi sendo substituído aos poucos e as salas receberam o nome de um naturalista nacional ou estrangeiro, tal como na exposição antropológica. Após esse período de adaptações, o edifício só foi novamente modificado com Roquette-Pinto depois de 1928 (Castro Faria, 1998, p. 70).

Durante a gestão de Batista de Lacerda, além das reformas físicas, novas reformas administrativas foram realizadas. O decreto $n$. 3.211, de 11/02/1899 (Brasil, 1899) modificou o regulamento de 1876 nos seguintes pontos: os diretores e subdiretores de seção passam a ser denominados professores e assistentes; o Conselho Administrativo passa a compor a Congregação; permanecem as quatro seções, com seus respectivos laboratórios, denominadas (i) Zoologia, (ii) Botânica, (iii) Mineralogia-Geologia-Paleontologia e (iv) Antropologia-Etnologia-Arqueologia, agora acompanhadas por seus respectivos laboratórios; o cargo de Naturalista-Viajante foi suprimido, e as exposições passam a ser abertas ao público de quinta a domingo. Pelo decreto n. 7.862, de 09/02/1910 (Brasil, 1910), foram fundados três novos laboratórios: o de Química Vegetal, o de Entomologia Agrícola e o de Fitopatologia. Neste último regulamento, os cargos de Naturalista-Viajante, Substitutos e Preparadores foram restabelecidos.

Essas modificações imprimiram ao Museu Nacional uma dimensão prática de ciência que se juntou à tradição etnográfica introduzida desde a "Exposição Antropológica" de 1882. Esse processo culminou numa ênfase dada às investigações e pesquisas, que se tornaram cada vez mais postas a serviço da busca de soluções para o Brasil. Isso resultou na redefinição da finalidade da instituição por meio do decreto n. 9.211, de 15/12/1911 como "o estudo e a divulgação da Historia Natural, especialmente do Brazil" (Brasil, 1911, anexo), ainda durante a gestão de Batista de Lacerda. Esse período de intensas mudanças corresponde à consolidação do Museu Nacional como o espaço privilegiado de constituição da antropologia no Brasil, e que Roquette-Pinto encontrou quando nele ingressou em 1905. Ao esboço de Ladislau Netto, com suas linhas dedicadas à instrução pública e à formação de coleções (com destaque às coleções indígenas e arqueológicas), foi sobreposta a dimensão prática de ciência delimitada por Batista de Lacerda. Os primeiros anos do Museu Nacional no século XX combinavam, portanto, uma dupla ênfase, a dimensão etnográfica e a busca por uma ciência prática herdeira da história natural. 


\section{O museu como lugar de formação prática em antropologia}

Castro Faria, recuperando a história da antropologia no Brasil, apontava que a disciplina enquanto nome simples, praticada na passagem do século XIX para o século XX, não possuía adjetivos. Apenas antropologia, a disciplina "foi se constituindo como um saber construído e por muito tempo operante fora da academia, era um saber ligado à academia por outra especialidade sem a qual ela não poderia se desenvolver. Essa ciência como lugar já destacado na academia e nas universidades era a anatomia" (Castro Faria, 2006, p. 2). Quando Roquette-Pinto recupera o seu processo de entrada na antropologia menciona as aulas com Brant Paes Leme, segundo ele, "inesquecível professor" da cadeira de Anatomia, onde pela primeira vez teve contato com a "ciência das raças humanas" (Silveira, 1939, p. 46).

A sua monografia de conclusão de curso, Ethnographia americana: 0 exercicio da medicina entre os indigenas da America (Roquette-Pinto, 1906), é a primeira expressão da aliança do autor com a antropologia. Por meio desse trabalho é possível acessar as principais referências antropológicas que nortearam o trabalho do autor nos anos que antecedem seu ingresso no Museu Nacional. A análise dos dados apresentada em sua Ethographia americana já incorporava os métodos da etnografia e da antropometria (Souza, 1920, p. 216) e permite conhecer um pouco mais sobre o que Roquette-Pinto entendia por antropologia.

Um ponto fundamental desse trabalho reside na sua proposta: investigar as funções médicas nas sociedades indígenas da América. Imaginar um médico, no início do século XX, com todo o status e a distinção atribuída à sua função, dispor-se a contrapor tais práticas às indígenas, caracterizadas por sua "primitividade", é de fato um aspecto surpreendente da obra de Roquette-Pinto. O autor, apesar de não abdicar de tal caracterização, constrói sobre essas populações uma alteridade relativa em que, a cada "estágio evolutivo", as "funções médicas" vão se especializando até o "estágio atual".

No entanto, apesar da inovação de sua monografia, o primeiro trabalho confiado a Roquette-Pinto, logo após a sua nomeação como assistente do Museu Nacional, em 1906, diz respeito a uma antiga tradição de pesquisa do museu: a exploração dos sambaquis. Na ocasião, o então jovem médico foi enviado ao litoral do Rio Grande do Sul para o estudo dos sambaquis, um dos temas caros à época. Tais formações guardavam, em seu interior, importantes materiais 
arqueológicos, fonte de estudo para diversas especialidades. Quando Roquette-Pinto chegou ao litoral do Rio Grande do Sul, Barbosa Rodrigues, Batista de Lacerda e Miranda Ribeiro, para citar apenas pesquisadores vinculados ao Museu Nacional, já haviam há muito realizado pesquisas nessas formações.

$\mathrm{O}$ interesse pelas pesquisas em sambaquis advém do rico potencial que os materiais ali encontrados tinham para o desenvolvimento das teorias raciais em curso no século XIX. Rudolf Virchow, importante formulador da teoria da craniometria, professor em Berlim e um dos fundadores do Museu de Antropologia naquela cidade, tinha como base de estudo materiais advindos dos sambaquis de São Paulo e de Santa Catarina (São Francisco e Joinville) (Castro Faria, 2003, p. 126). Os crânios, os machados e demais artefatos lá encontrados foram fundamentais para o desenvolvimento da sua teoria sobre a relação entre as medidas craniométricas e as capacidades mentais dos sujeitos analisados. O reconhecimento internacional desses estudos, consolidado sobretudo pelos trabalhos da Sociedade Berlinense de Antropologia, Etnologia e Pré-História incentivou o desenvolvimento das pesquisas nacionais que dialogavam fortemente com essa perspectiva.

Além dos trabalhos com sambaquis e os desdobramentos daí decorrentes, Roquette-Pinto tomou parte em importantes congressos científicos onde pôde inserir-se em outras agendas de pesquisas. Dentre essas experiências, destaco o $4^{\circ}$ Congresso Médico Latino-Americano, ocorrido no Rio de Janeiro, em 1909, onde apresentou o trabalho intitulado "Ethnographia indigena do Brazil: estado actual dos nossos conhecimentos" (Roquette-Pinto, 1909). Nesse trabalho, ele indica a inexistência de uma história dos povos do Brasil (Roquette-Pinto, 1909, p. 1). Para compensar tais ausências, procede Roquette-Pinto à distribuição da população indígena de acordo com a sua ocupação territorial. Na faixa litorânea do Brasil indica os Tupi, ligados pelos "traços geraes de vida, e de rejião, como tambem as linguas que falavam" (Roquette-Pinto, 1909, p. 3). Os que não estavam nessa área eram os "erradios e ferozes, bestiaes e glutões [...] de animo inabordavel" (Roquette-Pinto, 1909, p. 3). Esses eram os Tapuia (Roquette-Pinto, 1909, p. 4). Ao contrário dos Tupis, a denominação Tapuia abrangia grupos diversos em costumes e linguagem que, no entanto, segundo $o$ autor, formavam uma única raça (Roquette-Pinto, 1909, p. 4).

Malik (1996, p. 71) ao analisar a produção do discurso de raça indica ser essa uma categoria que envolve uma relação mutável ao longo do tempo 
entre "humanidade", "sociedade" e "natureza". Para sua compreensão devemos entender os modos pelos quais essa relação tem sido formulada e reformulada e como, em determinados momentos, ela se condensa no discurso da raça. Mais que um único sentido para raça, precisamos compreender os seus múltiplos usos e não como mera portadora de um único fenômeno ou de uma relação. No caso do trabalho anteriormente citado de Roquette-Pinto, suas proposições acerca da raça apoiavam-se nos estudos de Von Martius; D'Orbigny e Ehrenreich, demonstrando a forte influência germânica na construção dos seus argumentos. O antropólogo recuperava, nesses autores, as classificações linguísticas dos povos do Brasil e suas rotas de migração, numa tentativa de conciliar os pontos divergentes a fim de produzir uma síntese.

Propunha Roquette-Pinto, por ser a língua um critério falho e um aspecto facilmente modificável, os costumes e outros possíveis aspectos para classificação dos povos do Brasil. Note-se que ao se referir a "costumes" o autor aponta para objetos: "o botoque para os Gês, as redes de fibras de palmeira para os Aruaks, as de algodão para os Carhibas, o tembetá para os Tupis" (Roquette-Pinto, 1909, p. 11-12). E, no aspecto físico, indica Roquette formarem um conjunto relativamente homogêneo, "são todos euticomi, mezorrinos, eurignatas, megazemas, embora de fenda palpebral estreita e obliqua". E, por isso, conclui o autor que "no Brasil, ninguem póde reconhecer, entre eles, mais de um tipo fizico" e que "no criterio antropolojico nada aproveita a classificação das nossas tribus". Os domínios etnográficos, por sua vez, são apontados igualmente como falhos devido às divisões linguísticas. Devem ser aceitos somente com reservas (Roquette-Pinto, 1909, p. 13).

Propõe o estudioso que se adote o elemento geográfico sem desprezar os dados linguísticos. Seu objetivo não era "fazer dos indios acidentes geograficos, caracteristicos a certas regiões; o que se quer é não separar cada tribu do seu ambito de digressões". Quanto à migração dos grupos, responde o autor que as delimitações se fazem em grandes faixas e respondem a "um fato real", "a intima relação do povo com o seu meio astronomico restrito" (Roquette-Pinto, 1909, p. 14, 16). Tal formulação advém dos critérios geolinguísticos propostos por Paul Ehrenreich.

O valor do trabalho de Roquette-Pinto reside em dois pontos. Primeiro, a síntese realizada das teorias de Von den Steinen, Ehrenreich e Von Martius e o esboço de classificação dos povos indígenas do Brasil segundo as orientações de Ehrenreich. Dada essa orientação, tal trabalho permite conciliar 
critérios primordialistas, como a língua e a raça, com a história das migrações, compondo assim um quadro mais amplo que foge da correspondência uma raça, uma nação formulada na passagem do século XVIII para o XIX (Malik, 1996, p. 55).

Ao se apropriar de tais referências, Roquette-Pinto colocou-se em posições bem distintas dos seus contemporâneos mais próximos acerca dos debates de mestiçagem e eugenia que explodiriam na década seguinte, sendo objeto de análise tanto da antropologia física quanto dos debates políticos mais amplos. Assim como Boas (2007), Roquette-Pinto deslocou o foco de atenção da dimensão específica da raça enquanto categoria científica para tornar-se um crítico ideológico dela, percebendo o valor relativo de todas as culturas. Enquanto Batista de Lacerda propunha formas de branqueamento da população mestiça do Brasil, Roquette-Pinto buscava instruir e educar as massas como meio para torná-las nacionais.

Tal oposição não se dava, no entanto, de modo polarizado. Em 1911, Roquette-Pinto, indicado pelo Museu Nacional na qualidade de assistente de Batista de Lacerda, foi enviado ao $1^{\circ}$ Congresso Universal das Raças. $O$ trabalho apresentado por Lacerda, "Sur les métis au Brésil" - buscava comprovar a viabilidade da tese de branqueamento para o caso da população brasileira em cem anos. E para isso, tinha por única prova estatística o trabalho fornecido por Roquette-Pinto. Segundo Castro Faria (1959), "o embraquecimento do brasileiro passou a ser considerado daí por diante não apenas um ideal, mas uma verdade científica; portanto, além de altamente apreciada, incontestável" (Castro Faria, 1959, p. 5). Para Seyferth (1985, p. 97-98), a proposição de Roquette-Pinto estava embasada por dados duvidosos e consistia numa projeção, admissível porque repleta de conteúdo ideológico.

Sejam pelos conteúdos ideológicos ou pela força da proposição científica, as considerações de Seyferth e Castro Faria indicam que os trabalhos apresentados pelo delegado brasileiro e seu assistente convenceram o público científico da viabilidade do branqueamento da população brasileira, ainda que seu prazo de realização fosse por vezes questionado. Após o importante evento, Roquette-Pinto partiu em missão oficial de quatro meses pela Europa, onde pôde frequentar as aulas de Brumpt, Tuffier, Verneau e Luschan (Lima; Sá, 2008, p. 61). Com os dois primeiros, teve a oportunidade de atualizar as técnicas de estudo fisiológico, com o terceiro, as de paleoantropologia, e com o quarto, discutir os sistemas de classificação a partir da tonalidade da pele. 
Não somente as atividades acadêmicas e a produção científica foram ocupadas por Roquette-Pinto durante os primeiros anos de atuação no Museu Nacional. Em 1910, tem-se notícia de que inaugurou a Filmoteca do Museu Nacional com o objetivo de produzir registros científicos e divulgar a ciência, posteriormente, enriquecida por meio de doações realizadas pela Comissão Rondon (Moreira; Massarani; Aranha, 2008, p. 260). Em 1911, apresentou ao Congresso Nacional, juntamente com Gustav Magnus, um projeto de tradução ao português de importantes obras de viajantes alemães, dentre as quais se destacavam os trabalhos de Johann Baptist von Spix e Carl Friedrich Philipp von Martius, Karl von den Steinen, Paul Ehrenreich, Max Schimidt, Koch-Grümberg e Fritz Krause. ${ }^{6}$ Não tendo sido aprovado, o projeto foi reapresentado ao Ministério da Agricultura e Comércio em 1917, também sem sucesso.

Em 1912, encontra-se Roquette-Pinto à frente da seção de Antropologia, Etnologia e Arqueologia do Museu Nacional, na qualidade de substituto eventual de Domingos Sérgio de Carvalho. Ele comanda as reformas físicas realizadas no setor, chegando mesmo a desentender-se com setores administrativos do Museu para o atendimento aos seus pedidos. ${ }^{7}$ Ainda em 1912, foi Roquette-Pinto quem escreveu ao Jornal do Commercio em defesa do ministro da Agricultura, Pedro de Toledo. Solicitava que fossem retiradas as acusações de abandono das coleções arqueológicas publicadas contra o ministro. ${ }^{8}$ Em sua defesa, apresentava a assinatura do regulamento de 1912 e a contratação de um Conservador em Arqueologia destinado ao cuidado dessas coleções como provas de sua colaboração e cuidado.

Como é possível perceber, em meados de 1912, Roquette-Pinto estava perfeitamente integrado às atividades do museu. Participara de importantes congressos internacionais e nacionais, publicara trabalhos significativos, assumira as atividades administrativas da $4^{\text {a }}$ Seção e mantinha canais de diálogo com importantes atores externos à instituição. Quando houve a possibilidade de

6 Projeto manuscrito apresentado ao Congresso Nacional da República dos Estados Unidos do Brasil (Acervo Roquette-Pinto, Academia Brasileira de Letras, Pasta 27-05-23). O projeto de tradução de viajantes foi reapresentado em 1917 ao Ministro da Agricultura (Acervo Roquette-Pinto, Academia Brasileira de Letras, Pasta 28-01-22).

7 Cartas de Roquette-Pinto a P. A. Reeves, 13/03/1912 e 20/06/1912 (Arquivo Roquette-Pinto, Academia Brasileira de Letras, Pasta 27-5-03).

8 Carta de Roquette-Pinto ao Jornal do Commercio, 20/06/1912 (Arquivo Roquette-Pinto, Academia Brasileira de Letras, Pasta 27-5-03). 
seguir com Cândido Mariano Rondon para a região do atual estado de Rondônia, para lá se encaminhou não somente um pesquisador proficiente e interessado no saber acadêmico. O Roquette-Pinto que para lá se dirigiu era também comprometido com o projeto institucional do Museu Nacional e com o projeto de nação em curso. ${ }^{9}$ O período inicial de sete anos dedicados ao trabalho no Museu Nacional em conjunto com as experiências anteriormente descritas imprimiu uma forte dimensão etnográfica à perspectiva inicial de uma abordagem física do homem e de suas manifestações culturais.

O período em que esteve em campo entre os Nambiquara e Pareci no ano de 1912 foi de intensas pesquisas. Lá realizou as primeiras gravações fonográficas de cânticos indígenas, um minucioso estudo antropométrico de suas populações e formulou uma prodigiosa coleção etnográfica. Os ganhos conquistados para antropologia e etnografia brasileiras com a expedição de Roquette-Pinto, em 1912, podem ser comparados na divulgação dos métodos da antropologia e em termos de escalas nacionais aos trabalhos de Malinowski, iniciados em 1914, apenas dois anos depois da expedição à Serra do Norte. Em termos de formação de coleções, por sua vez, pode ser comparada às expedições de Von den Steinen ao Xingu; de Rivers e Haddon ao Estreito de Torres; e de Boas ao norte do Canadá. Oliveira (2006) chega mesmo a afirmar que o patrimônio cognoscitivo formado por essas iniciativas foi único e decisivo para que a antropologia "viesse a ser efetivamente a disciplina científica que conhecemos e cuja genealogia traçamos".

O estudo, portanto, dessas iniciativas e dos modos de produção dos seus sentidos através dos museus e de suas exposições torna-se fundamental para compreendermos como a antropologia se constituiu na primeira metade do século XX. Num período em que inexistiam programas de pós-graduação e graduações dedicadas à formação do antropólogo, os museus se constituíram quase como as corporações de ofícios medievais, onde para se constituir como mestre o aprendiz necessitava superar o seu professor. Roquette-Pinto, ingresso no Museu Nacional como auxiliar de Batista de Lacerda, após a viagem à Serra do Norte e da publicação de Rondônia havia superado os preceitos que recebeu em sua chegada ao museu. Fundava ali uma outra perspectiva de

9 Para uma análise minuciosa da expedição de Roquette-Pinto à região de Rondônia, ver Santos (2011). 
prática antropológica, intimamente relacionada ao museus, suas exposições e à tradição germânica de abordagem do espaço geográfico, das línguas e das culturas. As formas como esses aspectos foram materialmente constituídos são o ponto de análise do próximo tópico.

\section{A refundação antropológica das exposições do Museu Nacional e do Museu Paulista}

Após o retorno de Roquette-Pinto da região de Rondônia, ainda em 1912, foi dado início a um largo processo de distribuição e divulgação dos objetos etnográficos trazidos. Proponho neste tópico apresentar parte do destino desses objetos e de seus rearranjos, numa tentativa de conhecer suas trajetórias e os seus usos para que deles se possam inferir seus significados produzidos em outros contextos acerca das populações às quais estavam referidos (Appadurai, 2008, p. 17). Tal proposição vem a juntar-se às formulações de Fabian (2010) e Kopytoff (2008) acerca do valor desse empreendimento para alcançar "suas identidades materiais e temporais específicas" (Fabian, 2010, p. 66) e suas redefinições quando colocados em uso (Kopytoff, 2008, p. 93).

As coleções formadas por Roquette-Pinto no contexto da Comissão Rondon possuíam, além de objetos exclusivos e únicos, vários elementos duplicados. Isso, que se pode chamar de excedente, era colecionado justamente para favorecer as trocas institucionais, outro poderoso mecanismo utilizado para formar coleções não acessíveis pelas instituições por meio de seus recursos (humanos e financeiros) próprios. Além disso, os objetos duplicados eram uma das formas de estabelecer parcerias e de divulgar as pesquisas em curso. A Coleção Roquette-Pinto seguiu, em parte, esse destino.

As primeiras remessas dos objetos dessa coleção ocorreram no ano de 1916, para o Museu de La Plata, Argentina. Em 1918, seguiram-se remessas para o Museu Goeldi, no Pará; para o Museu Paulista, em São Paulo e para a República Argentina, sem a especificação do museu destinatário. Ainda em 1918, uma coleção foi remetida à Europa com o fim explícito de permuta. Em 1920, o rei da Bélgica, visitando o Museu Nacional, levou uma parte. Em 1921, a Escola Normal de Artes e Ofícios Wenceslau Braz, no Rio de Janeiro, e museus norte-americanos receberam coleções por meio da atuação de Berta Lutz, que havia 
sido enviada para aquele país com o intuito de estudar o papel educativo dos museus norte-americanos. Em 1922, mais uma vez com a intermediação de Lutz, aos museus norte-americanos foram destinados objetos. E, em 1926, foi a vez da delegação da antiga Tchecoslováquia. Depois disso, novas saídas somente ocorreram em 1957, para o Instituto de Neurologia, e em 1971, à Escola de Comunicação do Ministério do Exército. ${ }^{10}$

Remontando o percurso de divulgação e de circulação dos objetos da Serra do Norte, pode-se indicar como primeira ação facilitadora desse processo, sem dúvida, a publicação de Rondônia, na revista Arquivos do Museu Nacional. $\mathrm{O}$ alcance de distribuição da revista ${ }^{11}$ e o reconhecimento por ela acumulado contribuíram para legitimação tanto do livro produzido (texto, imagens, método de investigação), quanto do autor. Não se pode esquecer de que em Rondônia há uma larga explicitação dos objetos pertencentes à Coleção Roquette-Pinto. E com isso, o reconhecimento à obra tornou-se, em parte, o próprio reconhecimento à coleção.

Outra obra destacada no rol de textos que contribuíram à divulgação do acervo do Museu Nacional é Anthropologia: guia das colleções (Roquette-Pinto, 1915). Esse guia vinha sendo preparado desde 1912, junto com os trabalhos de reorganização e catalogação das coleções da $4^{\mathrm{a}}$ Seção. As duas atividades buscavam fornecer ao público as informações que ele requeria ao Museu Nacional (Roquette-Pinto, 1912). Nessa obra, Roquette-Pinto privilegiou os domínios da antropologia física, não constando nela nenhum objeto da Serra do Norte e do Vale do Juruena.

No guia, como o próprio autor indica na introdução, buscou-se, em linguagem simples e acessível, explicar as bases fundamentais da antropologia, e não realizar um catálogo do museu (Roquette-Pinto, 1915, p. 3). Tal proposta não poderia ter sido mais satisfatória para as expectativas da época. Além de alcançar seu propósito inicial, informar as massas em linguagem simples e direta, seu horizonte foi lançado ainda mais longe. No Relatório Geral de $1922,{ }^{12}$ ele é

10 Informações do livro de tombo do Museu Nacional, Setor de Etnologia e Etnografia.

11 Que incluía todos os continentes e destinos como URSS, Austrália, Japão, Egito e São Salvador, dentre muitos outros. Para uma análise da circulação das revistas, ver Agostinho (2014).

12 Relatório Geral de 1922 enviado ao Ministério da Agricultura Indústria e Comércio (MAIC), depositado no Setor de Memória e Arquivo. 
apontado, com a revista Arquivos do Museu Nacional, como os embaixadores do museu junto aos principais centros científicos do mundo, responsáveis, assim, pelo aumento do prestígio da instituição.

Os resultados da reformulação das exposições, iniciada com a preparação do guia, foram menos divulgados, porém, não menos impactantes. Em 1914, Domingos de Carvalho, chefe da seção de Antropologia, Etnologia e Arqueologia, anunciava a conclusão de grande parte da reforma expositiva relativa à $4^{\mathrm{a}}$ Seção (Carvalho, D., 1914). Em 1915, com a finalização da nova organização, ele explicitava quais foram os critérios adotados, "entendi que nos era forçoso conciliar, tanto quanto possível, a maneira de dispor o material etnográfico nas salas e galerias que lhe competem com a distribuição geográfica das tribos que eles representam, adotado o critério de localizá-las consoante as bacias fluviais dos territórios sobre que elas assentam" (Carvalho, D., 1915, p. 2). Como as coleções do Museu Nacional não possuíam elementos de todos os grupos apontados, propôs Domingos de Carvalho completar os dados com fotografias, desenhos, etc. Sugeria ainda a produção de quadros murais por bacia fluvial com a indicação dos grupos extintos e existentes ${ }^{13}$ (Carvalho, D., 1915, p. 2).

Domingos de Carvalho buscava orientar os esforços da seção em proveito da generalização. Não pela compreensão de algumas povos indígenas, mas das diversas regiões etnográficas do Brasil. Ao estudo do homem primitivo (físico, emocional, intelectual), acreditava dever-se conjugar o estudo dos fatores externos, contribuindo-se assim para o conhecimento do clima, do solo, da geografia, da botânica e da zoologia (Carvalho, D., 1915, p. 3). Para mim, parece clara a disposição de Domingos de Carvalho de reformular o modelo expositivo instituído em 1882, pela primeira Exposição Antropológica. Nesse, a totalidade da vida da aldeia buscava ser representada por meio da reprodução das cenas nativas. Agora, buscava-se uma apresentação científica para os objetos, que passava pela sua associação com o meio físico (ver Figuras 1 e 2, dos dois momentos).

13 Os quadros-murais foram, pela primeira vez, utilizados por Ladislau Neto após o regulamento de 1876 numa tentativa de elaborar materiais didáticos aos cursos públicos. No Relatório Geral de 1922, a distribuição de quadros-murais é apontada como uma alternativa, já em prática, à diminuição da distribuição de coleçães. Tal ação visava dar continuidade ao alcance do ensino das ciências naturais promovido pelo Museu Nacional. 


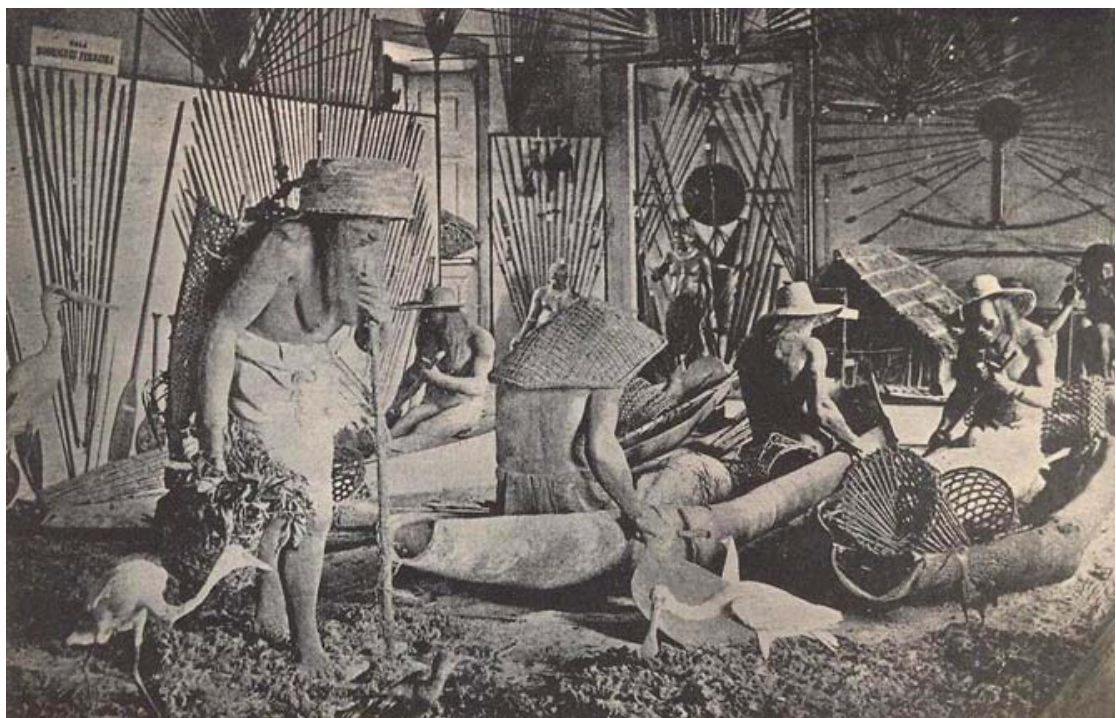

Figura 1. Exposição Antropológica de 1882 (fonte: Setor de Fotografia do Museu Nacional).

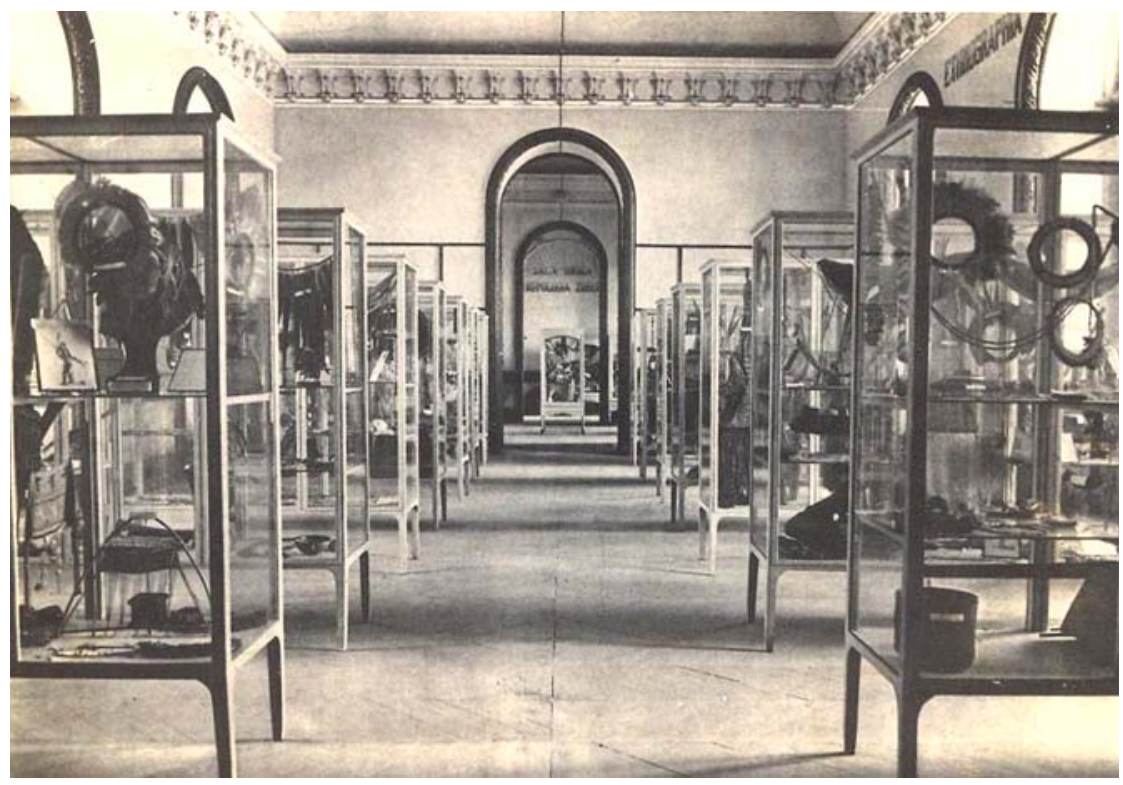

Figura 2. Vista da Sala Gabriel Soares, ao fundo Sala Broca (fonte: Setor de Fotografia do Museu Nacional). 
Se, no guia de antropologia do Museu Nacional, Roquette-Pinto optou por não incluir os materiais provenientes de Rondônia, nem as orientações postas em curso por Domingos de Carvalho, na reformulação da sala Etnografia Brasileira, do Museu Paulista, a opção será em parte contrariada. A pedido de Affonso Taunay, na época diretor em comissão do Museu Paulista, para lá se dirigiu Roquette-Pinto em março de 1918, permanecendo até abril do mesmo ano. ${ }^{14}$ Ia incumbido da tarefa de reorganizar aquela sala da instituição, que há muito vinha sendo negligenciada pelo diretor anterior, Von Ihering.

Von Ihering havia sido o primeiro diretor do museu, fundado em 1894, cargo que ocupou até 1917, quando foi substituído por Affonso Taunay. O Museu Paulista havia sido idealizado como um marco celebratório da independência. Nesse sentido, tanto o palácio construído quanto o museu que passou a funcionar nos anos seguintes constituem dois processos correlacionados com aquele momento. O palácio foi projetado por Tommaso Gaudenzio Bezzi e levou quase dez anos para ficar pronto. Quando concluídas as obras, cerca de cinco anos depois o edifício recebeu a coleção do coronel Joaquim Sertório, que constituiu sua base de fundação. Sertório era um homem influente na sociedade paulistana, comerciante e membro da Guarda Nacional. Havia acumulado muitos recursos que o permitiram se dedicar ao colecionismo de objetos os mais diversos. Constituíam suas coleções moedas, louças, instrumentos musicais, itens de história natural como espécimes de plantas, amostras de madeira, fósseis, animais empalhados, objetos indígenas, dentre outros.

Embora desprovida de sistematização científica e seguindo o modelo de organização dos gabinetes de curiosidades, a Coleção Sertório chegou a ser organizada em um formato de museu prévio ao Museu Paulista atraindo visitantes, compondo um conjunto de naturalistas e realizando exposições em parceria com outras instituições, como a realizada com o Museu Paraense Emílio Goeldi. Em face do desejo de Sertório de se desfazer das coleções em 1890, Francisco Paula Mayrink, político e empresário, procedeu à aquisição e à doação das coleções ao Museu Paulista (Carvalho, M., 2015, p. 143). Além dessas coleções, fizeram parte do conjunto inicial que fundou o Museu Paulista os materiais do Museu Provincial da Associação Auxiliadora do Progresso de São Paulo; as coleções particulares de Pessanha e de von Ihering (Lopes, Figuerôa, 2003, p. 27).

14 Cartas de Taunay a Bruno Lobo, Semear/MN, P79, doc. 158 e 189. 
Foi Von Ihering quem promoveu os primeiros contornos da instituição, imprimindo uma marca acentuada de pesquisas e exposições em história natural. ${ }^{15}$ Há uma vasta bibliografia que trata da sua atuação no período formativo do Museu Paulista, bem como de sua experiência prévia e do seu reconhecimento enquanto cientista. Desse conjunto, destacamos os trabalhos de Margaret Lopes e Silvia Figuerôa (2003), Fábio Moraes (2008) e de Lilia Schwarcz (2004), que apontam para sua importância nos campos da zoologia e da paleozoologia, e que, de certo modo, foi legada à instituição. A ênfase na história natural impressa por Von Ihering viria a ser substituída por uma perspectiva mais histórica com a entrada de Taunay na direção.

Affonso D’Escragnolle Taunay foi diretor do Museu Paulista de 1917 a 1945 e ao longo dessas quase três décadas produziu uma virada histórica na instituição, convertendo-o em "lugar de memória" da história nacional (Brefe, 2005). Procedendo a uma minuciosa pesquisa histórica, Taunay foi recompondo as coleções históricas do Museu Paulista com farta documentação colonial. Mapas cartográficos, cartas, livros de notas entre muitos outros ocuparam o interesse do diretor. Além disso, Taunay procedeu à remodelagem das exposições do museu convidando para isso especialistas de cada área. Na área de Etnologia e Antropologia convidou Edgar Roquette-Pinto para reformulá-la.

Na sala Etnografia Brasileira, Roquette-Pinto providenciou não somente a inclusão das novas peças nambiquara (levadas com ele em 1918), como promoveu também o rearranjo de toda a sua disposição. Antes expostas sem identificação e em prateleiras, as peças foram indexadas e redistribuídas nas oito vitrines disponíveis (interior e parte superior) e nas paredes acima das vitrines, conforme sua procedência geográfica (ver Figuras 3 e 4) (Taunay, 1919, p. 898, 1937, p.103). Ao entrar na sala, à direita, o visitante deparava-se com objetos indígenas da Guiana brasileira, em seguida, do Amazonas, do Brasil Central, do Mato Grosso, do Espírito Santo, de Minas Gerais e, por fim, de São Paulo (Taunay, 1937, p. 103).

15 A atuação de Von Ihering como diretor do Museu Paulista foi marcada por muitas controvérsias, sobretudo em relação aos seus posicionamentos em relação aos modos como a questão indígena deveria ser conduzida. Tal controvérsia foi motivada especialmente a partir dos conflitos entre índios kaingang e migrantes alemães que haviam passado a ocupar suas terras no interior de São Paulo. Para Von Ihering a solução seria o extermínio da população indígena, posicionamento que foi fortemente combatido pelos colaboradores da Comissão Rondon, entre eles Roquette-Pinto (Lima, 1985, 1990; Lima; Santos; Coimbra Jr., 2005). 


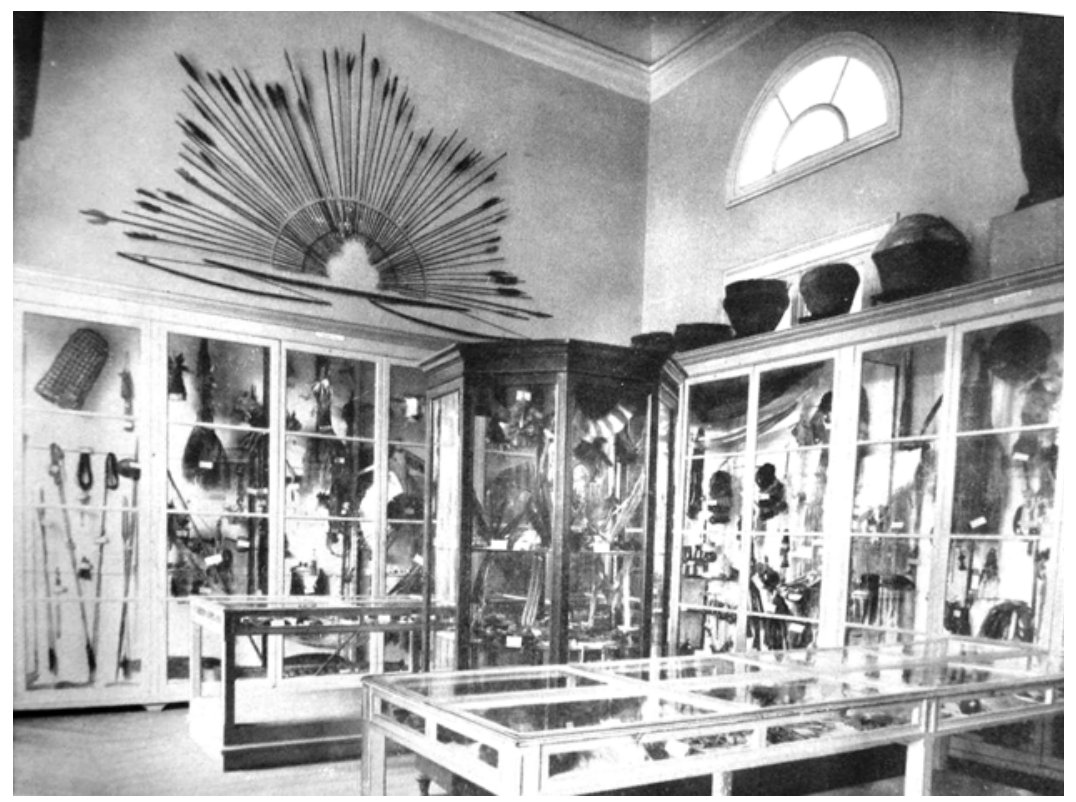

Figura 3. Etnografia Brasileira (Sala B-12) (fonte: Guia da Seç̧ão Historica do Museu Paulista).

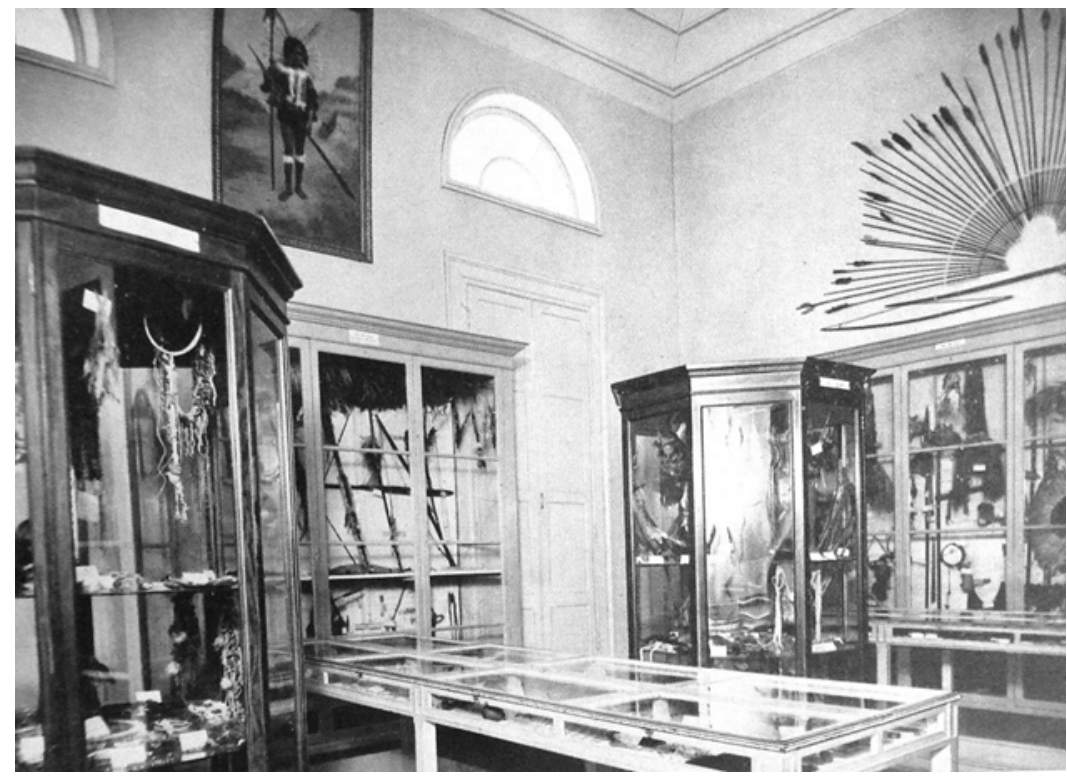

Figura 4. Etnografia Brasileira (Sala B-12) (fonte: Guia da Secção Historica do Museu Paulista) 
Muito embora o padrão de seleção de armas, com a apresentação de flechas, arcos, bordões, tacapes, machados e outros, continue a ser recorrente para montagem das exposições (ou, nesse caso, de remodelagem), houve espaço para inserção de outras tipologias. Na nova sala, encontravam-se os elementos rituais e musicais indígenas, assim como os de sua organização social e os estéticos. Os diademas de penas, os braceletes, os cocares, as flautas e os abanos dos índios de Rondônia dividiam o espaço com as máscaras de dança, o calendário indígena, colares, instrumentos musicais dos Tucano e dos Tariana e as cabeças mumificadas dos índios jivaro e dos Mundurucu do Tapajós, entre outros objetos (Taunay, 1937, p. 104).

Na apresentação dos objetos, pelo Guia da Secção Historica, a descrição oscilava entre elogios à técnica indígena e indicações de sua primitividade, exotismo e nível de civilização. O calendário dos Tucano e dos Tariana era classificado como "curioso"; os diademas de penas dos índios de Rondônia, "grandes e magníficos"; e as flautas de taquara ornadas, marcadas "pela sua primitividade" (Taunay, 1937, p. 103-104). A despeito dessas considerações acerca dos objetos, o parecer sobre a reformulação realizada por Roquette-Pinto é a de que ele imprimiu uma "feição altamente esthetica", revertendo o quadro de má impressão e de desvalorização da coleção característico do arranjo anterior (Taunay, 1919, 1937, p. 103).

O guia histórico, publicado pelo Museu Paulista anos depois, cuidou de consagrar essa reformulação (Taunay, 1937). O guia detinha parte da proposta idealizada para Anthropologia: guia das collecções do Museu Nacional e buscava oferecer ao visitante, esclarecimentos sobre as principais particularidades do acervo histórico do Museu Paulista - inaugurado à visitação de modo amplamente reformado no bojo das comemorações do centenário da independência do Brasil (Taunay, 1937, p. 3-4). Para tal comemoração no Rio de Janeiro, Roquette-Pinto investiu seus esforços no que denominou "estudo dinâmico, biológico, dos nossos objetos e de nossas condições naturais" (Roquette-Pinto, 1922). Trata-se do estudo das características antropométricas e dos estudos de antropologia fisiológica da população brasileira, naquele ano levado ao seu grau máximo (Roquette-Pinto, 1922).

Não obstante a ênfase em 1922 nos estudos antropométricos, após a morte de Domingos Sérgio de Carvalho, em agosto de 1924, houve a nomeação de Roquette-Pinto para cargo de chefe da seção de Antropologia, Etnologia e 
Arqueologia. Dada a composição da seção que ele passou a administrar, a partir daí, entraram em curso novas reformulações expositivas, nas quais o espaço destinado à etnografia foi consagrado juntamente com os estudos antropométricos. Roquette-Pinto reconhecia, como a grande contribuição de Sérgio Carvalho ao Museu Nacional, a inserção científica por ele promovida desde 1910. No entanto, passados 14 anos, entendia ser "chegado de sobra o momento de modificar a organização atual do Museu, de modo a que os seus serviços de ensino público sejam cada vez mais úteis" (Roquette-Pinto, 1924).

Para tanto, realizou ainda no ano de 1924, a revisão do catálogo geral que contava com 17.777 espécimes de antropologia e de etnografia, ${ }^{16}$ deu início à preparação da segunda edição do guia de antropologia, com inclusão de diagramas e figuras, à classificação do material no depósito - realizada em pequena escala devido tanto à deficiência de pessoal como pela ausência de bibliografia (a ser suprida pelas novas aquisições) e ao estudo do material recolhido para determinação das características antropológicas da população do Brasil - que se tornaria o seu grande projeto de pesquisa nos anos 1930 (Roquette-Pinto, 1924).

Cinco anos depois, é possível ter notícias do resultado do empreendimento de Roquette-Pinto iniciado naqueles anos. Em 1929, então como diretor do Museu Nacional, ${ }^{17}$ anuncia a reformulação completa das salas expositivas da instituição. Agora, o público contava com 13 espaços amplamente reformados, cujo percurso era: (i) Antropologia física; (ii) Idade do homem (ainda em organização em 1929); (iii) O homem na América (Pedra); (iv) Paleoetnografia. Cerâmica. Brasil; (v) Cerâmica moderna. Brasil; (vi) Cerâmica. América; (vii, viii, ix, $\mathrm{x}$ ) Coleções etnográficas (distribuição do material dos diferentes grupos indígenas, dispostos por ordem geográfica); (xi) Populações regionais do Brasil atual (etnografia sertaneja); (xii) Etnografia estrangeira; (xiii) Arqueologia clássica. ${ }^{18}$

16 Roquette-Pinto promoveu revisões sucessivas do catálogo da seção de Antropologia, Etnologia e Arqueologia. Alípio de Miranda, em 1917, afirmava ser essa a única seção do Museu Nacional a ter um catálogo "graças ao esforço do Dr. Roquette" (Ribeiro, 1945, p. 27).

17 Cargo assumido em 1927 e no qual permaneceu até 1936 quando deixou a instituição para se dedicar exclusivamente à Rádio Sociedade.

18 Relatório Geral de 1929 enviado ao Ministério da Agricultura Indústria e Comércio (MAIC), depositado no Setor de Memória e Arquivo. 


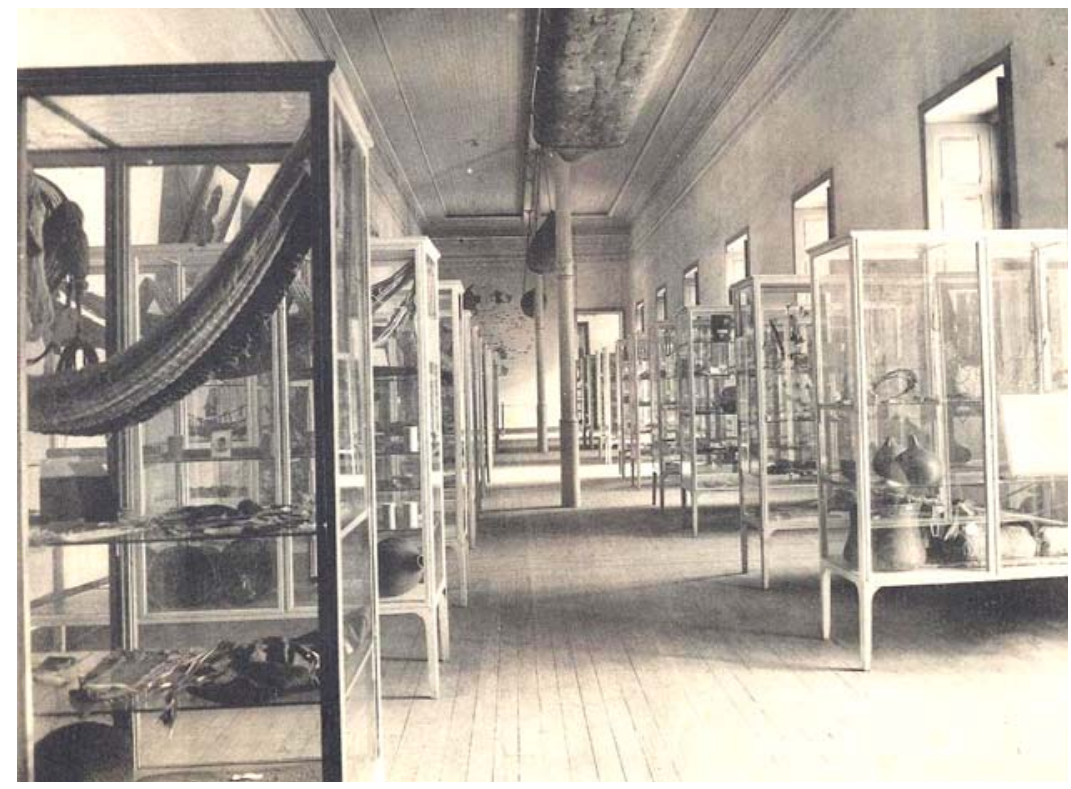

Figura 5. Sala Castelnau, Etnografia do Brasil. A imagem da sala dá uma mostra da visão interna do edifício nesse momento (fonte: Semear/MN).

Pelos critérios utilizados por Roquette-Pinto na reformulação da sala Etnografia Brasileira, do Museu Paulista e por sua aproximação com as teorias de Bastian e Ratzel é bastante provável que ele tenha dado prosseguimento ao arranjo das peças etnográficas do Museu Nacional conforme a distribuição geográfica das populações indígenas, associando-a aos aspectos linguísticos, ao invés das bacias hidrográficas proposta por Domingos de Carvalho. Inaugurava-se assim no Museu Nacional uma nova relação entre antropologia e discursos expositivos.

O sucesso dessa reorganização nos espaços expositivos e nos catálogos do Museu Nacional foi de tal modo significativo que, em 1929, tem-se notícias de que os métodos utilizados no museu serviam como modelo ao Museu do Trocadéro, em Paris. ${ }^{19}$ No ano anterior, Paul Rivet havia passado dois meses trabalhando no Museu Nacional, estudando seus métodos de organização. Ele

19 Relatório Geral de 1929 enviado ao Ministério da Agricultura Indústria e Comércio (MAIC), depositado no Setor de Memória e Arquivo. 
então teria recolhido três modelos diferentes de catálogo a fim de utilizá-los no Trocadéro, do qual era diretor. E, no ano seguinte, havia enviado uma carta indicando sua utilização. Além de sua admiração pelas coleções, as formas de classificação e organização lhe foram de tal modo surpreendentes, que assim registrou suas impressões no livro de visitas do Museu Nacional, em 14 de setembro de 1928:

Personne n'a le droit de parler d'ethnographie brésilienne s'il n'a visité et étudié en détail les admirables collections du Musée National de Rio de Janeiro. Jamais je ne me suis autant instruit que pendant les trops courtes semaines que j'ai pasées á Rio. J'en emporte un souvenir délicieux.

\section{Considerações finais: o exercício da antropologia nos museus brasileiros na primeira metade do século XX}

Ao longo do artigo vimos como os museus Nacional e Paulista postularam uma relação bastante próxima e, diríamos, indissociável da antropologia. Inicialmente formulada a partir de uma ênfase física, cientificista e nacionalista, que marcou as primeiras décadas dessa associação ainda no século XIX, essa relação passou para uma dimensão profundamente etnográfica e, por vezes, de compromisso político em relação aos povos representados, sobretudo a partir das primeiras décadas do século XX, com a atuação de Edgar Roquette-Pinto. A passagem entre uma e outra dimensão não provocou necessariamente a supressão da primeira, tendo o aspecto nacionalista e cientificista coexistido com a dimensão etnográfica.

Observando essa relação, podemos afirmar que a história dos museus (notadamente do Museu Nacional e do Museu Paulista) se confunde com a própria história da antropologia brasileira. Concentrando no período que vai do concurso de Edgar Roquette-Pinto para o Museu Nacional, em 1905, até a sua saída para assumir a Rádio Sociedade, em 1936, podemos destacar por meio de sua trajetória três principais aspectos da relação entre museus e antropologia para o caso analisado.

O primeiro aspecto diz respeito ao sentido da ciência da época que conformou as bases da atuação do antropólogo no museu. A formação em antropologia 
não correspondia nesse período a mais do que uma dimensão positivista ou meramente desdobrada da história natural. Partindo de uma formação médica, a experiência de se converter em antropólogo combinava a dimensão dos estudos físicos com a observação dos aspectos culturais das populações indígenas. Isso foi visto, sobretudo, a partir da análise do material de conclusão de curso de Edgar Roquette-Pinto (1906), Ethnographia americana: o exercicio da medicina entre os indigenas da America.

Essa passagem e formação em antropologia, num período em que inexistiam graduações na área, deu-se fortemente na formação prática empreendida pelos museus. Essa formação envolvia a aproximação com outras correntes teóricas; no caso da trajetória de Roquette-Pinto foram determinantes os estudos germânicos por meio das obras de Ratzel, de Von den Steinen, de Eherenreich e de Von Martius. A geografia e a língua forneceram assim o contraponto teórico sobre o qual o antropólogo debruçou-se na conformação de sua análise sobre as populações autóctones.

Ainda no museu, cabia ao antropólogo a proposição de um conjunto muito amplo de atividades de divulgação científica, que envolvia desde a formulação de revistas, catálogos até a proposição e a reformulação das exposições. E aqui aparece uma segunda dimensão bastante forte da antropologia nos museus nesse período - a sua função de comunicação pública. Não se trata de modo algum de uma antropologia de gabinete encerrada entre quatro paredes, mas de uma proposta que se desdobra para uma leitura do mundo nativo a ser comunicada com o grande público. O trabalho de comunicação e de divulgação científica era ainda acompanhado de um trabalho voltado ao ensino e à educação escolar por meio da organização de duplicatas, quadros murais, cursos de formação e de constituição de um setor específico de diálogo com o público - a Seção de Assistência ao Ensino (SAE) do Museu Nacional.

Por fim, gostaria de destacar o último aspecto da relação estabelecida entre a antropologia e os museus nesse período, a dimensão do compromisso político com o colecionismo e com as populações autóctones estudadas. Ainda partindo da análise da trajetória de Roquette-Pinto, ele afirmava em seu livro Rondônia: "Quem sabe si mais tarde, um filho da Rondonia, bisneto de alguns desses que deixei com saudade em 1912, educado por um sucessor do Mestre, si o houver capaz de recolher a herança, não folheará estas notas, para liga-as ao 
material conhecido e traçar, assim, a noticia completa do seu povo?" (Roquette-Pinto, 2005, p. XV)

A aposta de Roquette-Pinto com a formação de coleções para os museus não estava restrita somente ao momento de sua coleta e exibição; ou, ainda, à sua própria produção científica. Ela apontava para um horizonte futuro no qual imaginava os descendentes daqueles grupos buscando em seus registros os caminhos necessários para reconstrução da sua própria trajetória. Estamos hoje no final do horizonte imaginado por Roquette-Pinto, o futuro no qual os descendentes daqueles grupos acessam o ensino superior, frequentam os museus e elaboram para aqueles objetos colecionados novas interpretações e sentidos. Cabe agora a nós, antropólogos situados entre os museus e a universidade, traçar novos horizontes e futuros possíveis - que a trajetória dos que nos precederam, seus sonhos e investimentos políticos nos sirvam como inspiração para essa construção. Agora, não mais sozinhos, mas ao lado daqueles que por tanto tempo frequentaram apenas as vitrines.

\section{Referências}

AGOSTINHO, M. de B. O museu em revista: a produção, a circulação e a recepção da revista Arquivos do Museu Nacional (1876/1887). 2014. Dissertação (Mestrado em História) - Instituto de Ciências Humanas e Filosofia, Universidade Federal Fluminense, Rio de Janeiro, 2014.

ANDERMANN, J. Espetáculos da diferença: a Exposição Antropológica Brasileira de 1882. Topoi, v. 5, n. 9, p. 128-170, 2004.

APPADURAI, A. (org.). A vida social das coisas: as mercadorias sob uma perspectiva cultural. Niterói: Editora da Universidade Federal Fluminense, 2008.

BENCHIMOL, J. L. Domingos José Freire e os primórdios da bacteriologia no Brasil. História, Ciências, Saúde - Manguinhos, Rio de Janeiro, v. 2, n. 1, p. 67-98, mar.jun. 1995.

BOAS, F. Raça e progresso. In: CASTRO, C. (org.). Franz Boas: antropologia cultural. Rio de Janeiro: Jorge Zahar, 2007. p. 67-86.

BRASIL. Decreto $n^{\circ}$ 1.171, de 17 de Dezembro de 1892. Organiza o Laboratorio de Bacteriologia. Rio de Janeiro, 1892. Disponível em: http://www2.camara.leg.br/legin/ fed/decret/1824-1899/decreto-1171-17-dezembro-1892-505515-publicacaooriginal-1-pe.html. Acesso em: 28 jan. 2018. 
BRASIL. Decreto $n^{\circ}$ 3.211, de 11 de Fevereiro de 1899. Approva o regulamento para o Museo Nacional. Rio de Janeiro, 1899. Disponível em: http://www2.camara.leg.br/ legin/fed/decret/1824-1899/decreto-3211-11-fevereiro-1899-538913-publicacaooriginal-36289-pe.html. Acesso em: 28 jan. 2018.

BRASIL. Decreto $n^{\circ} 7.862$, de 9 de Fevereiro de 1910. Reorganiza o Museu Nacional. Rio de Janeiro, 1910. Disponível em: http://www2.camara.leg.br/legin/fed/decret/1910-1919/ decreto-7862-9-fevereiro-1910-503025-publicacaooriginal-1-pe.html. Acesso em: 28 jan. 2018.

BRASIL. Decreto $n^{\circ}$ 9.211, de 15 de Dezembro de 1911. Dá novo regulamento ao Museu Nacional. Rio de Janeiro, 1911. Disponível em: http://www2.camara.leg.br/legin/fed/ decret/1910-1919/decreto-9211-15-dezembro-1911-502745-norma-pe.html. Acesso em: 28 jan. 2018.

BREFE, A. C. F. O Museu Paulista: Affonso de Taunay e a memória nacional, 1917-1945. São Paulo: Ed. Unesp: Museu Paulista, 2005.

CARVALHO, D. S. Relatorio da $4^{a}$ Secção encaminhado a Batista Lacerda, director do Museu Nacional. Rio de Janeiro, 1914.

CARVALHO, D. S. Relatorio da $4^{a}$ Secção encaminhado a Batista Lacerda, director do Museu Nacional. Rio de Janeiro, 1915.

CARVALHO, M. P. De uma "cientificidade difusa": o coronel e as práticas colecionistas do Museu Sertório na São Paulo em fins do século XIX. Anais do Museu Paulista, São Paulo, v. 23, n. 2, p. 189-210, jul./dez. 2015.

CASTRO FARIA, L. A contribuição de Edgar Roquette-Pinto para a antropologia brasileira. Rio de Janeiro: Museu Nacional, 1959.

CASTRO FARIA, L. Antropologia: espetáculo e excelência. Rio de Janeiro: Ed. UFRJ, 1993.

CASTRO FARIA, L. Antropologia: escritos exumados: espaços circunscritos: tempos soltos. Niterói: Editora da Universidade Federal Fluminense, 1998.

CASTRO FARIA, L. Antropologia: escritos exumados 2: dimensões do conhecimento antropológico. Niterói: Editora da Universidade Federal Fluminense, 1999.

CASTRO FARIA, L. Virchow e os sambaquis brasileiros: um evolucionismo antidarwinista. In: DOMINGUES, H. M. B., SÁ, M. R.; GLICK, T. (org.). A recepção do darwinismo no Brasil. Rio de Janeiro: Editora Fiocruz, 2003. p. 125-143.

CASTRO FARIA, L. Antropologia: duas ciências. Notas para uma história da antropologia no Brasil. Brasília: CNPq; Rio de Janeiro: Mast, 2006.

FABIAN, J. Colecionando pensamentos: sobre os atos de colecionar. Mana, Rio de Janeiro, v. 16, n. 1, p. 59-73, 2010. 
GARCIA, A. Fundamentos empíricos da razão antropológica: a criação do PPGAS e a seleção das espécies científicas. Mana, Rio de Janeiro, v. 15, n. 2, p. 411-447, 2009.

KODAMA, K. Os índios no Império do Brasil: a etnografia do IHGB entre as décadas de 1840 e 1860. Rio de Janeiro: Editora Fiocruz; São Paulo: Edusp, 2009.

KOPYTOFF, I. A biografia cultural das coisas: a mercantilização como processo. In: APPADURAI, A. (org.). A vida social das coisas: as mercadorias sob uma perspectiva cultural. Niterói: Editora da Universidade Federal Fluminense, 2008. p. 89-121.

LACERDA, B. Fastos do Museu Nacional do Rio de Janeiro: recordações historicas e scientificas fundadas em documentos authenticos e informações veridicas. Rio de Janeiro: Imprensa Nacional, 1905.

LIMA, A. C. S. Aos fetichistas, ordem e progresso: um estudo do campo indigenista no seu estado de formação. 1985. Dissertação (Mestrado em Antropologia Social) Museu Nacional, Universidade Federal do Rio de Janeiro, Rio de Janeiro, 1985.

LIMA, A. C. S. O Santo Soldado: pacificador, bandeirante, amansador de índios, civilizador dos sertões, apóstolo da humanidade. Uma leitura de Rondon conta sua vida de Esther de Viveiros. Rio de Janeiro: Museu Nacional/UFRJ, 1990. (Comunicação n. 21).

LIMA, N. T.; SÁ, D. M. de. Roquette-Pinto e sua geração na república das letras e da ciência. In: LIMA, N. T.; SÁ, D. M. de (org.). Antropologia brasiliana: ciência e educação na obra de Edgar Roquette-Pinto. Belo Horizonte: Editora UFMG; Rio de Janeiro: Editora Fiocruz, 2008. p. 57-84.

LIMA, N. T.; SANTOS, R. V.; COIMBRA Jr., C. E. A. Introdução à Rondônia de Edgard Roquette-Pinto. In: ROQUETTE-PINTO, E. Rondonia: anthropologia-ethnographia. 7. ed. Rio de Janeiro: Editora Fiocruz, 2005. p. 25-39.

LOPES, M. M. O Brasil descobre a pesquisa científica: os museus e as ciências naturais no século XIX. São Paulo: Hucitec, 1997.

LOPES, M. M.; FIGUEIRÔA, S. F. de M. A criação do Museu Paulista na correspondência de Hermann von Ihering (1850-1930). Anais do Museu Paulista, São Paulo, v. 10-11, n. 1, p. 23-35, 2003.

MALIK, K. The meaning of race. London: Mac Millan, 1996.

MORAES, F. R. Uma coleção de história em um museu de ciências naturais: o Museu Paulista de Hermann von Ihering. Anais do Museu Paulista, São Paulo, v. 16, n. 1, p. 203-233, jan./jun. 2008.

MOREIRA, I. C.; MASSARANI, L.; ARANHA, J. Roquette-Pinto e a divulgação científica. In: LIMA, N. T.; SÁ, D. M. de (org.). Antropologia brasiliana: ciência e educação na obra de Edgar Roquette-Pinto. Belo Horizonte: Editora UFMG; Rio de Janeiro: Editora Fiocruz, 2008. p. 247-270. 
NASCIMENTO, F. R. A formação da coleção de indústria humana no Museu Nacional, século XIX. 2009. Tese (Doutorado em Antropologia Social) - Museu Nacional, Universidade Federal do Rio de Janeiro, Rio de Janeiro, 2009.

NETTO, L. Investigações historicas e scientificas sobre o Museu Imperial e Nacional do Rio de Janeiro. Rio de Janeiro: Instituto Philomatico, 1870.

NETTO, L. Relatorio do Museu Nacional apresentado ao Illm. Exm. Sr. Conselheiro José Fernandes da Costa Pereira Júnior, Ministro e Secretario de Estado dos Negocios da Agricultura, Commercio e Obras Publicas. Rio de Janeiro: Typographia do Diario do Rio de Janeiro, 1875.

NETTO, L. Le Muséum National de Rio de Janeiro et son influence sur les sciences naturelles du Brésil. Paris: Librairie CH. Delagrave, 1889.

OLIVEIRA, J. P. de. Apresentação. In: RONDÔNIA 1912: gravações históricas de Roquette-Pinto. Rio de Janeiro: Laced/Museu Nacional/UFRJ, 2006.

OLIVEIRA, J. P. de. Dos museus para as pós-graduações: iniciada com as expedições científicas a antropologia no Brasil se especializou no contexto universitário. Revista de História, Rio de Janeiro, v. 2, p. 70-73, 2010.

OLIVEIRA, J. P. de. O nascimento do Brasil e outros ensaios: "pacificação", regime tutelar e formação de alteridades. Rio de Janeiro: Contracapa, 2016.

OLIVEIRA, J. P. de; SANTOS, R. de C. M. Descolonizando a ilusão museal - etnografia de uma proposta expositiva. In: LIMA FILHO, M. F.; ABREU, R.; ATHIAS, R. (org.). Museus e atores sociais: perspectivas antropológicas. Recife: Editora UFPE: ABA, 2016. v. 1, p. 125-155.

RIBEIRO, A. M. A Comissão Rondon e o Museu Nacional. 2. ed. Rio de Janeiro: Ministério da Agricultura/Comissão Nacional de Proteção aos Índios, 1945.

ROQUETTE-PINTO, E. Ethnographia americana: o exercicio da medicina entre os indigenas da America. Rio de Janeiro: E. Bevilacqua \& C., 1906.

ROQUETTE-PINTO, E. Ethnographia indigena do Brazil: estado actual dos nossos conhecimentos. Rio de Janeiro: Imprensa Nacional, 1909.

ROQUETTE-PINTO, E. Relatorio da $4^{a}$ Secção de Anthropologia e Ethnographia apresentado ao Sr. Director do Museu Nacional, Bruno Lobo. Rio de Janeiro: Arquivo Semear/ MN, 1912.

ROQUETTE-PINTO, E. Anthropologia: guia das collecções. Rio de Janeiro: Typographia da Directoria Geral de Estatistica, 1915.

ROQUETTE-PINTO, E. Relatorio da $4^{a}$ Secção apresentado ao Director do Museu Nacional, Bruno Lobo. Rio de Janeiro: Arquivo Semear/MN, 1922. 
ROQUETTE-PINTO, E. Relatorio da $4^{a}$ Secção apresentado ao Director do Museu Nacional, Bruno Lobo. Rio de Janeiro: Arquivo Semear/MN, 1924.

ROQUETTE-PINTO, E. Rondonia: anthropologia-ethnographia. 7. ed. Rio de Janeiro: Editora Fiocruz, 2005.

SANTOS, R. de C. M. "No coração do Brasil": Roquette-Pinto e a expedição à Serra do Norte. 2011. Dissertação (Mestrado em Antropologia Social) - Museu Nacional, Universidade Federal do Rio de Janeiro, Rio de Janeiro, 2011.

SCHWARCZ, L. M. O espetáculo das raças: cientistas, instituições e questão racial no Brasil, 1870-1930. São Paulo: Companhia das Letras, 2004.

SEYFERTH, G. A antropologia e a teoria do branqueamento da raça no Brasil: a tese de João Batista de Lacerda. Revista do Museu Paulista, São Paulo, n. 30, nova série, p. 81-92, 1985.

SILVEIRA, J. A inquietação artística de Roquette-Pinto. Vamos Ler, Rio de Janeiro, p. 46, 22 mar. 1939.

SOUZA, A. P. Notas sobre os costumes dos indios nhambiquaras. Revista do Museu Paulista, t. 12, p. 390-405, 1920.

STOCKING Jr., G. W. Race, culture and evolution. Chicago: The University of Chicago Press, 1982.

TAUNAY, A. E. Relatorio referente ao anno de 1918, apresentado ao Senhor Secretario do Interior, Dr. Oscar Rodrigues Alves, pelo Director em Commissão, do Museu Paulista, Affonso D’Escragnolle Taunay. Revista do Museu Paulista, São Paulo, t. 9, p. 801920, 1919.

TAUNAY, A. E. Guia da Seç̧ão Historica do Museu Paulista. São Paulo: Imprensa Official do Estado, 1937.

TILLEY, C. et al. (ed.). Handbook of material culture. London: Sage, 2006.

VELOSO JÚNIOR, C. R. Os “curiosos da natureza”: Freire-Allemão e as práticas etnográficas no Brasil do século XIX. 2013. Dissertação (Mestrado em História) Instituto de Ciências Humanas e Filosofia, Universidade Federal Fluminense, Niterói, 2013.

WOLF, E. Europe and the people without history. Los Angeles: University of California Press, 1982.

Recebido: 31/01/2018 Aceito: 6/11/2018 | Received: 1/31/2018 Accepted: 11/6/2018 